\title{
The Web-Based Usability Heuristic Survey Supports User Satisfaction
}

\author{
E Wijayanto', O C C Tavares ${ }^{2}$, A Santos ${ }^{3}$ \\ ${ }^{1}$ Universitas Atma Jaya Yogyakarta, Indonesia \\ ${ }^{2}$ Dili Institute of Technology, Rua Ai-Meti Dili, Timor Leste \\ ${ }^{3}$ Instituto Profissional De Canossa Avenida, Delta Comoro, Dili, Timor Leste \\ E-mail: 195303130@students.uajy.ac.id¹,ofelia tavares@yahoo.com², \\ apolisantos871@gmail.com ${ }^{3}$
}

Submitted: 8 August 2020, revised: 28 August 2020, accepted: 29 August 2020

\begin{abstract}
Abstrak. Persaingan antar perusahaan kini semakin kuat terkait dengan mekanisme perusahaan dalam memberikan layanan yang diberikan. Perusahaan dapat membangun cara untuk mempertahankan loyalitas pelanggan. Pendekatan tersebut dapat dilakukan dengan metode usability testing berbasis web dengan mengadopsi model penerimaan pengguna aplikasi. Ini merupakan analisis aspek usability di sisi pelanggan sebagai pengguna yang menikmati produk dan layanan perusahaan. Saat ini sudah banyak teori model penerimaan pengguna untuk suatu aplikasi. Salah satunya adalah model kepuasan pengguna atau user satisfaction. Ulasan ini secara khusus juga mengidentifikasi bahwa konten memiliki pengaruh positif yang signifikan terhadap kepuasan pengunjung situs web.
\end{abstract}

Kata kunci : kegunaan; kepuasan pelanggan, situs web

\begin{abstract}
Competition between companies is now getting stronger strongly related to the company's mechanism in providing the services provided. Companies can build ways that can maintain customer loyalty. The approach can be done with web-based Usability Testing adopting an application user acceptance model, a usability aspect analysis that acts as a customer who enjoys a company's products and services. At present, there are already many theories of user acceptance models for an application. One of them is the user satisfaction model (User Satisfaction). This review specifically also identifies that content content has a significant positive effect on website visitor satisfaction.
\end{abstract}

Keywords : usability; user satisfcation; web

\section{Introduction}

Web-based applications are used in companies to support product marketing activities and quality in service. Currently there are many websites that present a variety of information. But many of them are not able to meet the main purpose of developing a website. In one report stated that $60 \%$ of the time is 
wasted because people cannot find the information they need on a website. Of course this has an impact on decreased productivity, increased stress, and various other forms of loss. [1]. External factors include conditions that facilitate or hinder the attitude of IT use, whereas factors internally focused on the planning process in individual users which is covered by consideration to ultimately decide whether to use IT or not [2]. Facing the application usability is defined as the process of optimizing interactions between users and the system that can be done interactively, so users get the right information or complete an activity on the application better [3].

According to Landauer [4], most of the total cost of software development is used for maintenance because of user interaction problems with the system and not technical problems. The situation above illustrates the importance of usability analysis to emphasize the need for application development, before, during and after the software development process [5]. Nielsen [6] defines usability as a user experience in interacting with an application system so that in the end the user can operate it quickly and easily. In another study, Dix [7] conveyed four criteria in conducting a usability study. The four criteria are effectiveness, efficiency, satisfaction and learnability, security [8].

Website usability consist of several things, such as time of data receipt (download delay), page navigation (navigation or organization), interactivity, responsiveness, website material information (content), successful websites (user satisfaction) [9]. The usability measurement concept is based on an approach issued by Microsoft Usability Guideline. In their research, they arranged usability categories and subcategories with weights and rating schemes [10]. The comparison of the other research models, especially in usability studies, some of them are Green and Pearson [11] who compared the Agarwal and Venkatesh models with the Palmer model through the Confirmatory Factor Analysis (CFA) method. The results of the study indicate that the Palmer model's CFA results better meet the recommended standards. Green and Pearson [12] formulated the four best dimensions to measure user satisfaction with a website, namely by determining measurement variables that were judged to have a stronger value (robust) but very appropriate (parsimonious). To analyze the relationship and influence (cause-effect) of two or more phenomena [13] through hypothesis testing.

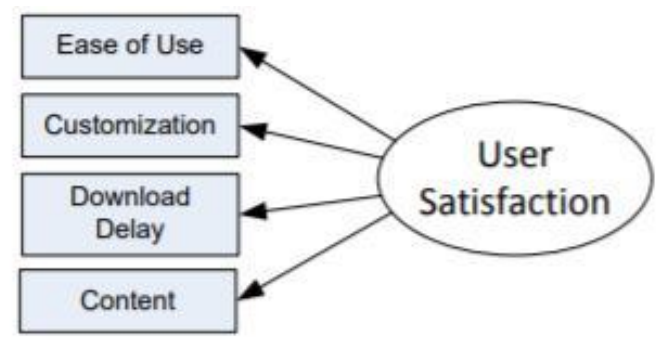

Figure 1. Research Survey Model

Cooper and Schindler [14] revealed that research based on theories or hypotheses that would be used to test a phenomenon that was classified as explanatory research (explanation). In accordance with the analysis model used in this study, namely Structural Equation Model (SEM), the variables used include exogenous variables, indicator variables (measured variables / observed variables), and endogenous variables. In this study, the sample size is adjusted to the analysis model used, namely the Structural Equation Model (SEM). In this regard, the sample size for SEM using the maximum likelihood estimation (MLE) is 100-200 samples or as much as 5-10 times the number of variables estimated [15]. management needs to understand, that the website visitors of this application tend to want to find a more specific information and pay less attention to the general ease of using or operating the application [16].

The results of this study will be a reference for the development team in making improvements to the system and become a guideline in carrying out interface and interaction design activities. Interface design evaluation is part of the discipline of human and computer interaction or often abbreviated as IMK. Whereas interaction design is defined as the design of interactive products to support daily life 
[17]. Evaluation can be defined as a process in determining the usefulness and acceptability of a product and its design, which is measured in various criteria. [18], namely: a. See how far the function of a system can run b. See the effect of the interface for the user, and c. Identifying specific problems that occur in the system. The opinion of the evaluator becomes a reference for multilevel improvement to the system developer [19]. Mobile Uses Heuristic Evaluation Method (Lestari, PA., Et al., 2019) which provides recommendations on the PLN Mobile application interface using heuristic evaluation [20].

\section{Theoretical Framework}

\subsection{Heuristic Evaluation}

According to Alan Dix et al. in Human Computer Interaction 3rd Edition, heuristic evaluation is a guideline or general principle or rule of thumb that guides the design of a decision or is used to check the decision that has been made. The idea is to give an evaluator a way to criticize the system to produce potential uses.

\subsection{Heuristic Evaluation Rules}

In evaluating a design, there are 9 rules to note [21], namely:

1. Visibility of system status

This point means that the system must always keep giving feedback to users about what is happening. For example, if the operating system will take time, the system will give an indication of how long until the process is complete.

2. Match between system and the real world

The system must represent the real world of its users, such as the use of words, sentences, and concepts that are recognized in everyday life.

3. Use control and freedom

The user must be able to freely choose the main work required. The system must be able to allow users to work freely, such as providing undo or redo.

4. Consistency and standard

Users do not need to ask questions about the way the system is used, because the method used will be the same even though the context is different.

5. Error prevention

The system must be able to avoid errors. Error messages are a good thing but avoiding mistakes before they occur is better.

6. Recognition rather than recall

Users do not need to question again about differences in understanding of actions, the word in sentences, and also the situations. All must follow the standards.

7. Flexibility and efficient of use

The system must be able to accommodate a variety of types of users, such as advanced users, new users, or users who have different conditions.

8. Help users recognize, dialogue, and recovers from errors

The system must be able to help users not to fall into errors in the system. Instructions in the system must be made clear and easy to remember.

9. Help and documentation

The system has good and relevant documentation and also has a help feature, so users don't feel they are working and are left alone.

\section{Discussion}

In this section we will discuss in more detail the first two points of heuristic evaluation rules, specifically the visibility of system status and also the match between system and the real world. 


\subsection{Visibility of system status}

Visibility of System Status is information provided by the application or the web to the user that shows the current conditions of what the user is doing in the application. Every action taken by the user certainly has meaning and the user needs a feedback from every action taken. In the visibility system status, of course a clear clue is very important and sometimes small things like this are often forgotten by the developer.

\subsection{Match between system and the real world}

The system must use concepts that represent the real world, such as symbols and words. Information from a system is certainly very much and complicated. This complicated language is only understood by developers and technicians from the system alone. In general, users are lay people and do not need to learn or know the technical terms of the system to complete the tasks of the system. Because it is necessary to exploit the system so that it can be recognized and can be used by ordinary people by displaying a variety of views or general terms that are easy to understand.

These issues were not addressed at the time of the design [22] and implementation of the system can can trigger inadequate interactions between system and user [23]. To detect this problem, the usefulness of the system's user interface must be evaluated [24]. There are various methods to evaluate and improve the information system user interface, for instance Heuristic Evaluation (HE). HE has characteristics such as rapid and low cost [25]. The user will be evaluated using a checklist adapted to the principles previously mentioned.

Table 1. The severity rating of usability issues by Nielsen

\begin{tabular}{ll}
0 & This is not a usability problem at all \\
\hline 1 & $\begin{array}{l}\text { Cosmetic problem only - Does not need to be fixed unless } \\
\text { extra time is available on the project }\end{array}$ \\
\hline 2 & $\begin{array}{l}\text { Minor usability problem - Fixing this should be given low } \\
\text { priority }\end{array}$ \\
\hline 3 & $\begin{array}{l}\text { Major usability problem - Important to fix, should be given } \\
\text { high priority }\end{array}$ \\
\hline 4 & Usability catastrophe - Imperative to fix
\end{tabular}

Many entries are used to determine conformity with the design concept of each user interface [26] aims to evaluate other systems such as systems for sensors [27] [28], the web for educational resources [29] and online training [30] use usability evaluation methods such as user testing [31][32] and also performance testing [33].

The Yen and Thyvalikakath studies [34][35] are two examples of research in the health care field, both comparing heuristic evaluation with user testing [36][37]. Nielson [38] recommend that heuristic evaluation is work most suitable with three effective evaluators. Therefore, to increase the credibility of the research results, we took eight evaluators in the information technology field. The evaluators used different terms only to describe the same issues [39]. Then those most typical descriptions are used to duplicate the problem. [40] The three factors that explained before such as the number of problems, the potential effect on the users, and also their persistence. The average severity score given by eight evaluators for each problem is recorded as the final severity score (in the table).

Number of studies compare the usual heuristic evaluation method with other usefulness evaluation methods such as cognitive-trace user testing through [41], thinking-aloud and performance testing [42]. Studies have shown that the assessment of training skills will avoid a system designed to produce bad results. [43]. which ultimately [44] improves the results of the method [45]. Methods can be used to design detailed interfaces compared to user testing methods that find user needs [46]. The results of this study can help evaluators of information systems, select the appropriate method to evaluate the usefulness of its use. 


\section{Conclusion}

This survey discusses the introduction of web-based usability whose function is to support product marketing activities and quality of service. One of the researchers stated that heuristic evaluation is a guideline or general principle or rule of thumb that guides the design of a decision or is used to check the decision that has been made. That allows usability on a web to function properly when used. The main objective is to form a usability heuristic and combine it and test the field directly by combining existing research and reference in development, and it is hoped that through this survey readers can gain additional knowledge about usability heuristics with the bassist website.

\section{References}

[1] U.S. Department of Health \& Human Services, "Usability Basics," U.S. Government. [Online]. Available: http://www.usability.gov.

[2] H. Jetter and J. Gerken, "A Simplified Model of User Experience for Practical Application," 2nd Int. Open Work. COST294-MAUSE, 2006.

[3] H. S. Sastramihardja, "Perancangan Kerja dalam Perangkat Lunak, Interaktif," J. Inform. ITB, vol. 1, pp. 13-16, 1999.

[4] Y. J. Yoon and T. K. Landauer, "The Trouble with Computers: Usefulness, Usability, and Productivity," South. Econ. J., 1996.

[5] M. D. Lozano, F. Montero, and P. González, "A Usability and Accessibility Oriented Development Process," in 8th ERCIM Workshop on "User Interfaces For All", 2004.

[6] J. Nielsen, "Guerrilla HCI: Using discount usability engineering to penetrate the intimidation barrier," Cost-justifying usability, 1994.

[7] A. Dix, J. Finlay, G. D.Abowd, and R. Beale, Human-Computer Interaction. New Jersey: Prentice Hall, 1993.

[8] A. Abran, W. Suryn, A. Khelifi, J. Rilling, A. Seffah, and F. Robert, "Consolidating the ISO Usability Models," in 8th Annual INSPIRE Conference, 2003.

[9] J. W. Palmer, "Web site usability, design, and performance metrics," Inf. Syst. Res., 2002.

[10] R. Agarwal and V. Venkatesh, "Assessing a firm's Web presence: A heuristic evaluation procedure for the measurement of usability," Inf. Syst. Res., 2002.

[11] D. T. Green and J. M. Pearson, "A confirmatory factor analysis of two web site usability instruments," in Proceedings of the Third Annual Workshop on HCI Research in MIS, 2004.

[12] D. T. Green and J. M. Pearson, "The examination of two web site usability instruments for use in B2C e-commerce organizations," J. Comput. Inf. Syst., 2009.

[13] U. Sekaran, Research and Markets: Research Methods for Business - A Skill Building Approach. 2003.

[14] D. R. Cooper and P. S. Schindler, Business Research Methods, 8th ed. New York, 2003.

[15] S. . Wijanto, "Structural Equation Modeling dengan LISREL 8.8.2 Konsep dan Tutorial," in structural equation modeling dengan LISREL 8.8.2 konsep dan tutorial, 2008.

[16] M. Aljukhadar and S. Senecal, "How the Website Usability Elements Impact Performance," in 15th Americas Conference on Information Systems 2009, AMCIS 2009, 2009.

[17] A. Dix, J. Finlay, G. D. Abowd, and R. Beale, Human-Computer Interaction Third Edition. 2016.

[18] A. Ridwan, "Pengukuran Usability Aplikasi Menggunakan Evaluasi Heuristik," J. Inf. Komput., vol. 12, pp. 218-228, 2007.

[19] F. N. Muhammad and A. D. Herlambang, "Evaluasi Desain Antarmuka Aplikasi Mobile BPJS Ketenagakerjaan Menggunakan Heuristic Evaluation," J. Pengemb. Teknol. Inf. dan Ilmu Komput. Univ. Brawijaya, 2018.

[20] P. A. Lestari, I. Aknuranda, and A. D. Herlambang, "Evaluasi Usability Pada Antarmuka Pengguna Aplikasi PLN Mobile Menggunakan Metode Evaluasi Heuristik," J. Pengemb. Teknol. Inf. dan Ilmu Komput., vol. 2, no. 1, pp. 2269-2275, 2019.

[21] J. Nielson, Jakob Nielsen's Ten Heuristics. 2005.

[22] S. S. Isfahani, R. Khajouei, M. Jahanbakhsh, and M. Mirmohamadi, "The evaluation of hospital 
laboratory information management systems based on the standards of the American National Standard Institute.," J. Educ. Health Promot., 2014.

[23] L. Ahmadian, R. Khajouei, S. S. Nejad, M. Ebrahimzadeh, and S. E. Nikkar, "Prioritizing Barriers to Successful Implementation of Hospital Information Systems," J. Med. Syst., 2014.

[24] R. Khajouei, A. Hasman, and M. W. M. Jaspers, "Determination of the effectiveness of two methods for usability evaluation using a CPOE medication ordering system," Int. J. Med. Inform., 2011.

[25] J. Nielsen, "Finding usability problems through heuristic evaluation," in Conference on Human Factors in Computing Systems - Proceedings, 1992.

[26] D. Pierotti, Heuristic Evaluation-A System Checklist. Xerox Corporation, 1995.

[27] G. L. Alexander et al., "Sensor systems for monitoring functional status in assisted living facility residents.," Res. Gerontol. Nurs., 2008.

[28] H. Monkman and A. Kushniruk, "A health literacy and usability heuristic evaluation of a mobile consumer health application," in Studies in Health Technology and Informatics, 2013.

[29] J. Choi and S. Bakken, "Heuristic evaluation of a web-based educational resource for low literacy NICU parents," in Studies in Health Technology and Informatics, 2006.

[30] L. P. Dringus and M. S. Cohen, "An adaptable usability heuristic checklist for online courses," in Proceedings - Frontiers in Education Conference, FIE, 2005.

[31] M. R. Davids, U. M. E. Chikte, and M. L. Halperin, "An efficient approach to improve the usability of e-learning resources: The role of heuristic evaluation," Am. J. Physiol. - Adv. Physiol. Educ., 2013.

[32] R. A. Virzi, J. F. Sorce, and L. B. Herbert, "Comparison of three usability evaluation methods: Heuristic, think-aloud, and performance testing," in Proceedings of the Human Factors and Ergonomics Society, 1993.

[33] T. P. Thyvalikakath, V. Monaco, H. Thambuganipalle, and T. Schleyer, "Comparative study of heuristic evaluation and usability testing methods," in Studies in Health Technology and Informatics, 2009.

[34] P. Y. Yen and S. Bakken, "A comparison of usability evaluation methods: heuristic evaluation versus end-user think-aloud protocol - an example from a web-based communication tool for nurse scheduling.," AMIA Annu. Symp. Proc., 2009.

[35] A. Doubleday, M. Ryan, M. Springett, and A. Sutcliffe, "Comparison of usability techniques for evaluating design," in Proceedings of the Conference on Designing Interactive Systems: Processes, Practices, Methods, and Techniques, DIS, 1997.

[36] L. Fu, G. Salvendy, and L. Turley, "Effectiveness of user testing and heuristic evaluation as a function of performance classification," Behav. Inf. Technol., 2002.

[37] J. Nielsen and T. K. Landauer, "Mathematical model of the finding of usability problems," in Conference on Human Factors in Computing Systems - Proceedings, 1993.

[38] R. Khajouei, L. W. P. Peute, A. Hasman, and M. W. M. Jaspers, "Classification and prioritization of usability problems using an augmented classification scheme," J. Biomed. Inform., 2011.

[39] J. Nielsen, "Severity Ratings for Usability Problems," Pap. Essays. 1995.

[40] R. Khajouei, M. Zahiri Esfahani, and Y. Jahani, "Comparison of heuristic and cognitive walkthrough usability evaluation methods for evaluating health information systems," $\mathrm{J}$. Am. Med. Informatics Assoc., 2017.

[41] M. W. M. Jaspers, "A comparison of usability methods for testing interactive health technologies: Methodological aspects and empirical evidence," Int. J. Med. Inform., 2009.

[42] P. Rezaei-Hachesu, E. Pesianian, and M. Mohammadian, "Evaluating usability of radiology information systems in hospitals of Tabriz University of medical sciences," Acta Inform. Medica, 2016.

[43] J. Horsky et al., "Complementary methods of system usability evaluation: Surveys and observations during software design and development cycles," J. Biomed. Inform., 2010.

[44] R. Khajouei and M. W. M. Jaspers., "The impact of CPOE medication systems' design aspects 
on usability, workflow and medication orders a systematic review," Methods of Information in Medicine. 2010.

[45] B. Middleton et al., "Enhancing patient safety and quality of care by improving the usability of electronic health record systems: Recommendations from AMIA," J. Am. Med. Informatics Assoc., 2013.

[46] A. Ramkumar et al., "Comparison of Heuristic Evaluation and Think Aloud Methods A Study in Radiotherapy Contouring Software," in Proceedings of the International Symposium on Human Factors and Ergonomics in Health Care, 2014. 